\title{
Weaknesses of Adjudication in the Face of Secret Evidence
}

Gus Van Harten

Osgoode Hall Law School of York University, gvanharten@osgoode.yorku.ca

Source Publication:

International Journal of Evidence and Proof. Volume 13, Issue 1 (2009), p. 1-27.

Follow this and additional works at: https://digitalcommons.osgoode.yorku.ca/scholarly_works (c) (i) $(9)$

This work is licensed under a Creative Commons Attribution-Noncommercial-No Derivative Works 4.0 License.

\section{Recommended Citation}

Van Harten, Gus. "Weaknesses of Adjudication in the Face of Secret Evidence." International Journal of Evidence and Proof 13.1 (2009): 1-27.

This Article is brought to you for free and open access by the Faculty Scholarship at Osgoode Digital Commons. It has been accepted for inclusion in Articles \& Book Chapters by an authorized administrator of Osgoode Digital Commons. 


\title{
Weaknesses of adjudication in the face of secret evidence
}

\author{
By Gus Van Harten* \\ Assistant Professor, Osgoode Hall Law School, York University, \\ Toronto
}

Abstract Since 2001, governments in Canada and the United Kingdom appear to have increasingly sought to use secret evidence in proceedings against individuals suspected of posing a security threat, relying on the courts to review and legitimate executive claims in closed proceedings. Yet, in the face of secret evidence, adjudicative decision-making is subject to several extraordinary weaknesses. First, the judge is precluded from hearing additional information that can come to light only if the individual or the public is aware of the executive's claims. Secondly, courts are uniquely reliant on the executive to be fair and forthcoming about confidential information and to characterise accurately the case for secrecy. Thirdly, the dynamic or atmosphere of closed proceedings may condition a judge to favour unduly the security interest over priorities of accuracy and fairness. Even where the use of secret evidence is not deemed to be irreparably unsafe or unfair, therefore, its admissibility must be premised on the acknowledgement and careful consideration of corresponding weaknesses in adjudication.

Keywords Closed proceedings; Confidentiality; National security; Judicial review

ecrecy is the source of a contradiction in the democratic state. While secrecy may be essential to the state's ability to ensure security, it also prevents citizens from making informed choices about how they wish to

Former legal adviser to the Commission of Inquiry into the Actions of Canadian Officials in Relation to Maher Arar, archival site: <http//epe.lac-bac.gc.ca/100/206/301/pco-bcp/commissions/ maher_arar/index.html>.

Email: gvanharten@osgoode.yorku.ca. I wish to thank Mark Aronson, Conor Gearty, Tom Poole, Paul Roberts, Craig Scott, James Stribopoulos, and the anonymous reviewers of the article for their helpful comments. All views and opinions expressed are those of the author.

doi:1350/ijep.2009.13.1.308 
be governed. ${ }^{1}$ Secrecy may be essential because the state must in some cases act in confidence to protect against clandestine threats; put simply, in the words of a judge of Canada's Federal Court, "secrecy is required in order to counter the activities of those who operate in secret'. ${ }^{2}$ To entrust security to the state is therefore to accept a measure of hidden government. Yet by precluding public scrutiny this trust in the state makes official error and abuse more likely. Bentham described publicity as 'the very soul of justice ... the keenest spur to exertion and the surest of all guards against improbity ${ }^{3}$ and there is no surer spark for cynicism about government than the knowledge that those in power may lawfully conceal their activities from outside scrutiny. ${ }^{4}$ For this reason, allowances for state secrecy call for special mechanisms of accountability.

The tensions arising from secrecy inform much of the debate about the relationship between national security and law. They reflect the underlying conflict of interest in hidden government whereby those who wield security powers also decide what to reveal to the public about their mistakes or misdeeds. ${ }^{5}$ This article focuses on how this conflict has the potential to infect the adjudicative process where secret evidence ${ }^{5}$ is relied on, purportedly for security reasons, in proceedings that affect an individual. Since 2001, governments appear to have increasingly resorted to secret evidence in cases against those suspected of involvement in terrorism and, as a result, courts have been asked in closed proceedings to validate executive claims that an individual poses a security threat. ${ }^{7}$ Such proceedings entail judicial review both of confidential information

1 J. S. Mill, On Liberty and Considerations of Representative Government (Penguin Books: London, 1974) $77-9$.

2 E. Dawson, 'The Federal Court and the Clash of the Titans: Balancing Human Rights and National Security' (2006) Address to the University of Manitoba Faculty of Law, 30 March 2006 $<$ http:/cas-ncr-ntero3.cas-satj.gc.ca/portal/page/portal/fc_cfen/Speeches>, accessed 16 October 2008.

3 J. Bentham, 'Draught of a New Plan for the Organization of the Judicial Establishment in France' in The Works of Jeremy Bentham, vol. 4 (Tait: Edinburgh, 1843) 316.

4 Note, 'Keeping Secrets: Congress, the Courts, and National Security Information' (1990) 103 Harv L Rev 906 at $910-14$.

5 M. Rankin, National Security: Information, Accountability, and the Canadian Security Intelligence Service' (1986) 36 UTLJ 249 at 252; S. D. Jordan, 'Classified Information and Conflicts in Independent Counsel Prosecutions: Balancing the Scales of Justice after Iran-Contra' (1991)91 Col L Rev 1651 at 1654-5; E. K. Yamamoto, 'White (House) Lies: Why the Public Must Compel the Courts to Hold the President Accountable for National Security Abuses' (2004) 68 Law \& Contemp Probs 285 at $288-9$.

6 'Secret evidence' is evidence to which the affected individual (and the public) is denied access; 'closed proceedings' are legal proceedings that permit secret evidence.

7 K. A. McKee, "Remarks on the Freedom of Information Act: The "National Security" Exemption in a Post 9/11 Era' (2007) 4 Regent I Int'l L 263 at 271-5; E. Yaroshefsky, 'Secret Evidence is Slowly Eroding the Adversary System: CIPA and FISA in the Courts' (2006) 34 Hofstra L Rev 1063 at 1081-3. 
supplied by the state and of the state's arguments for secrecy. The aim of this article is to examine the limitations of adjudication in the face of secret evidence. The argument is pitched at the level of general principle and it does not aspire to provide comprehensive treatment of existing case law in the United Kingdom or Canada. Its reasoning is informed more eclectically by a distillation of academic research and analysis, relevant case law, and the author's own experience in the conduct of closed proceedings.

It is accepted here that it is appropriate for courts to decide whether secret evidence should be allowed in judicial proceedings and, in turn, to assess secret evidence against the applicable legal standards. In some contexts, especially that of a criminal trial, constraints arising from secrecy will call for an adjudicator to bar such evidence and to require the executive either to disclose the information or to withdraw claims based on it. In other contexts, it may be desirable or permissible to admit secret evidence in light of such factors as the centrality of the evidence to the underlying case, the degree of impact on the individual's rights or interests, and the utility and effectiveness of available procedural adaptations. Once an initial decision is made that allowing secret evidence is not irreparably unsafe or unfair, the courts must turn to more specific issues of relevance, reliability, probity, and admissibility, and must scrutinise more precisely the rationales for secrecy so as to decide whether and how portions or aspects of the information can be disclosed to the affected individual or the public. ${ }^{8}$ In the course of a more detailed review, it may become apparent that the required level of secrecy is such that the original decision to allow a closed proceeding to go forward should be revisited.

In considering secret evidence, the courts confront three key limitations. First, the judge is foreclosed from hearing additional information and argument that can come to light only if the affected individual or the public is made aware of the executive's claims or the underlying record of confidential information. Secondly, in closed proceedings, courts are especially reliant on executive officials to supply and characterise confidential information and to justify the case for secrecy. Thirdly, the dynamic of closed proceedings in the security context may condition judges to favour unduly the interests of secrecy and security. These limitations do not necessarily reflect inherent weaknesses of courts although they do require that in some legal contexts-in light of the nature of the evidence and the individual rights or interests at stake-secret evidence must be barred outright. On the other hand, where the consequences for an individual are less serious, there is an important role for adjudicative review of the security activities of the state and,

8 I. Leigh, 'Secret Proceedings in Canada' (1996) 34 Osgoode Hall LJ 113 at 154. 
by extension, for secrecy. This role for adjudication as an accountability mechanism should be endorsed only after consideration of the full range of limitations that follow from the use of secret evidence. ${ }^{9}$

\section{Adjudicative context}

In recent years, the use of secret evidence in adjudicative proceedings involving individuals accused or suspected of posing a security threat appears to have been revived and intensified. Without undertaking systematic empirical analysis, this section briefly outlines indicative aspects of the present use of secret evidence for national security reasons in the United Kingdom and Canada and its judicial review.

\section{(a) Contemporary use of secret evidence}

The underlying rationales for national security confidentiality have not changed conceptually since 2001. These rationales arise mainly from the state's need to protect the identity of informers in order to facilitate the gathering of human source intelligence, to prevent the state's investigative activities and methods from being revealed to those who pose a security threat, and to honour commitments made to foreign governments as a condition of information sharing. These rationales are well known and widely accepted as providing legitimate bases for secrecy, while also raising the prospect of exaggeration and abuse. What has changed since 2001 is the sense of urgency that is attached to relevant threats and also, it would appear, the extent to which secret evidence may be introduced in proceedings against an individual. ${ }^{10}$ This article leaves aside the extraordinary measures adopted by the US government, including practices of rendition and

9 The authority of courts or other adjudicators to scrutinise executive decisions is also at times limited, both in intensity and scope, by the application of a narrow standard of review or standard of proof, or by the specified grounds for overtuming decisions: Constitutional Affairs Committee, The Operation of the Special Immigration Appeals Commission (SIAC) and the Use of Special Advocates, HC 323-II 2004-05 (evidence of a number of Special Advocates) 57-9; Joint Committee on Human Rights, Counter-Terrorism Policy and Human Rights: Draft Prevention of Terrorism Act 2005 Order (Contimuance in force of sections 1 to 9), HL Paper 122, HC 915, 14 February 2006, paras 55-66. Although not the focus of the present article, this attenuation of adjudicative review raises additional issues concerning the accuracy and faimess of adjudicative decisions that are based on secret evidence. Suffice it to say that such issues are another factor to consider in determining whether the limitations inherent in closed proceedings can be ameliorated by procedural adaptations designed to accommodate secret evidence. However, even within a highly interventionist framework of judicial review, the use of secret evidence raises nonetheless the limitations identified in the present article.

10 J. L. Dratel, 'Ethical Issues in Defending a Terrorism Case: How Secrecy and Security Impair the Defense of a Terrorism Case' (2003) 2 Cardozo Pub L, Policy \& Ethics J 81 at 104. 
extra-judicial imprisonment, ${ }^{11}$ in order to highlight responses in the United Kingdom and Canada that are not extra-judicial, but still imegular and troubling in their reliance on closed proceedings.

The baseline for further analysis is that the overarching prohibition on secret evidence in criminal proceedings remains well entrenched in the United Kingdom and Canada in that the courts retain the authority to decide whether the public interest calls for disclosure of evidence to an accused in order to protect the right to a fair trial. That right itself rests fundamentally on the accused's ability to know the case against him or her and to answer that case by testing the evidence and offering evidence and argument in reply. ${ }^{12}$ In the criminal context, dangers posed by secrecy to accuracy and faimess are often regarded as irreparable. Secrecy may be permitted in the investigation of alleged crimes in order to authorise investi= gative techniques aimed at acquiring disclosable evidence for trial, but it is rarely if ever tolerated at the trial itself. ${ }^{13}$ In contrast, secret evidence has been allowed in other contexts, including some that lead to long-term detention, most importantly (in the United Kingdom) in proceedings to determine whether a suspected terrorist may be detained on preventive grounds and (in both the United Kingdom and Canada) in proceedings to determine whether a foreign national may be detained because he or she is believed to pose a security threat.

Thus, in the United Kingdom, the Prevention of Terrorism Act $2005^{14}$ provides for the issuance of control orders to detain terrorist suspects; in Canada, pursuant to the Immigration and Refugee Protection Act $2001,{ }^{15}$ security certificates have been issued for the detention of foreign nationals. The origins of these regimes differ in that the Prevention of Terrorism Act 2005 draws on the history of detention powers exercised during the conflict in Northern Ireland ${ }^{16}$ whereas the security certificate regime in Canada remains rooted in the immigration law of detention and deportation. By extension, the Canadian regime applies only to non-citizens while the UK system of control orders extends, since 2005, beyond the immigration context to apply to nationals and non-nationals alike. That said, both regimes are comparable for present purposes because they allow secret evidence

11 M.L. Satterthwaite, 'Rendered Meaningless: Extraordinary Rendition and the Rule of Law' (2006) 75 George Wash L Rev 1333.

12 For example, A v Secretary of State for the Home Department [2004] UKHL 56, [2005] 2 AC 68 at [100] (Lord Hope) and [155] (Lord Scott); Joint Committee on Human Rights, CounterTerrorism Policy and Human Rights: Prosecution and Pre-Charge Detention, HL Paper 240, HC 1576 2005-06, paras 74-75.

13 See the discussion at Part 2(a) below.

14 Sections 1 and 2.

15 Section $77(1)$.

16 C. Gearty, Civil Liberties (Oxford University Press: Oxford, 2007) 114-17; G. Marcus, 'Secret Witnesses' [1990] Public Law 207 at 210-12. 
in order to justify the detention of an individual or the imposition of onerous restrictions on his or her place of residence, movements, contacts, and communications. While the degree of encroachment on liberty may vary according to whether the person who is incarcerated is given the option to leave the country, for example, it is clear that incarceration in any case has serious consequences for the individual. Both the United Kingdom and Canadian regimes may therefore be viewed as quasi-criminal given the extent to which they restrict liberty. ${ }^{17}$ As the Supreme Court of Canada recently stated: ${ }^{18}$

The consequences of security certificates are often more severe than those of many criminal charges. For instance, the possible repercussions of the process range from detention for an indeterminate period to removal from Canada, and sometimes to a risk of persecution, infringement of the right to integrity of the person, or even death.

The use of secret evidence to detain individuals has, unsurprisingly, generated controversy in both the United Kingdom and Canada. ${ }^{19}$ But this is not the only context in which secrecy powers have expanded. In Canada, for example, amendments in 2001 to the Criminal Code of Canada $1985^{20}$ allowed the executive, with court approval, to require a witness at a criminal trial to testify under oath at a closed investigative hearing in the absence of the accused. Also in 2001, amendments to s. 38 of the Canada Evidence Act 1985 gave the Attorney-General of Canada wide-ranging powers to block release in any proceeding of 'sensitive information', the disclosure of which the Attorney-General believes would harm national security, national defence, or international relations, even after a court concludes that disclosure would not cause such harm or that the information should nevertheless be disclosed in the public interest. Thus, there are numerous contexts in which the executive's powers to keep evidence secret, although known before 2001 , appear to have expanded. ${ }^{21}$

Different procedural contexts in which secrecy powers are exercised, and secret evidence admitted, will involve different sorts of consequences for the individual

17 Secretary of State for the Home Department v J] [2007] UKHL 45, [2008] 1 AC 385.

18 Charkaoui v Canada (Minister of Citizenship and Immigration and Solicitor General of Canada) 2008 SCC 38 (26 June 2008) (hereafter Charkaoui No. 2) at [54].

19 International Committee on the Elimination of All Forms of Racial Discrimination, Concluding Observations on the United Kingdom (10 December 2003, CERD/C/63/CO/11) para. 17; Joint Committee on Human Rights, above n. 12 at paras $42-43$.

20 Section $83.28(4)$.

21 C. Forcese, 'Clouding Accountability: Canada's Government Secrecy and National Security Law "Complex" ' (2004) 36 Ottawa L Rev 49 at 69-83. 
who is affected by adjudicative decision-making. ${ }^{22}$ Criminal proceedings obviously carry the prospect of criminal sanctions. However, administrative proceedings may also entail serious consequences for the liberty and mobility of the individual, potentially culminating in long-term detention or deportation, alongside lesser encroachments such as the removal of one's passport. ${ }^{23}$ Moreover, legal proceedings may have significant consequences for the individual without encroaching on his or her liberty or mobility. These include, for example, orders to pay a fine or damages, the seizure of property, the denial of security clearance, the acquisition and storage of personal information, adverse findings of misconduct by a commission of inquiry, or a refusal of access to government information. ${ }^{24}$

It is important to bear in mind the variety of procedural contexts in which the legitimacy of secret evidence may fall for consideration. Although secret evidence is entirely inappropriate in some contexts, in others it may be unavoidable or desirable as a means to facilitate independent review of the workings of hidden government. The circumstances for and implications of secret evidence also vary depending on the factual and legal issues at stake. Procedural adaptations of adjudication designed to accommodate secret evidence may be correspondingly flexible. The question is not simply whether it is appropriate to allow secret evidence, however vital that question may be. In some circumstances, it is also important to consider how to adapt the process on an informed and self-conscious basis where the use of secret evidence is not deemed to be irreparably unsafe or unfair.

\section{(b) Judicial review}

Since 2001, the legal terrain for secret evidence has been characterised by greater reliance on the courts to approve decision-making processes that involve closed proceedings and, in turn, to review and legitimate executive claims in such proceedings. In the United Kingdom and Canada, the use of secret evidence remains subject to review by courts or by specialised tribunals whose decisions may in turn be challenged in the courts. The role of the courts in this regard is constantly evolving as the different branches of the state confront and contest the use of closed proceedings in different contexts.

22 Leigh, above n. 8 at 150 .

23 E. Broxmeyer, 'The Problems of Security and Freedom: Procedural Due Process and the Designation of Foreign Terrorist Organizations under the Anti-Terrorism and Effective Death Penalty Act' (2004) 22 Berkeley J Int'l L 439 at 483.

24 P. Hanks, 'National Security-A Political Concept' (1988) 14 Monash U L Rev 114 at 132. 
Thus, in the United Kingdom, the issuance of control orders under the Prevention of Terrorism Act 2005 is subject to judicial approval ${ }^{25}$ or review ${ }^{26}$ in closed proceedings governed by Part 76 of the Civil Procedure Rules. The courts thus play the central role in the decision-making process. On the other hand, under the earlier regime of Part IV of the Anti-Terrorism, Crime and Security Act 2001, a certificate could be issued for the detention of a non-citizen ${ }^{27}$ and the individual could in turn appeal against the certificate to a tribunal of the Special Immigration Appeals Commission (SIAC), ${ }^{28}$ consisting of a High Court judge as chair, a second member drawn from a panel of judges with experience in immigration appeals, and a third member who was a lay person with experience in assessing security intelligence. 29 The SIAC tribunal would resolve the appeal after considering secret evidence and its decisions were subject to further appeal to the ordinary administrative law courts. This arrangement for issuing and reviewing certificates against non-citizens was the subject of the House of Lords decision in the Belmarsh case, ${ }^{30}$ which found that the Anti-Terrorism, Crime and Security Act 2001 regime violated the right to liberty and security of the person under the European Convention on Human Rights on the basis that it was a disproportionate response to the threat of terrorism and that its application to foreign nationals only, and not citizens, was unjustifiably discriminatory. ${ }^{31}$ In response, the Prevention of Terrorism Act 2005 was enacted. It allows for the use of secret evidence to detain citizens and foreign nationals alike, and it replaced the process of SIAC review with one of judicial scrutiny. Control orders are now subject to judicial approval or review in closed hearings at which relevant material can be withheld from the individual.

In Canada, much of the responsibility for adjudicative review in security proceedings, outside of the criminal context, is assigned to the Federal Court, at

25 Section 4.

26 Section 3.

27 H. Fenwick, 'The Anti-Terrorism, Crime and Security Act 2001: A Proportionate Response to 11 September?' (2002) 65 MLR 724 at 733; D. Bonner, Executive Measures, Terrorism aná National Security (Ashgate: Aldershot, 2007) 209.

28 SIAC was established in 1997 in response to the European Court of Human Rights' decision in Chahal v United Kingdom (1996) 23 EHRR 413 at [131] and [144]. D. Dyzenhaus, The Constitution of Law (Cambridge University Press: Cambridge, 2006) 163.

29 Bonner, above n. 27 at 265-6; B. Barder, 'Brian Barder explains why he resigned from the Special Immigration Appeals Commission', London Review of Books (18 March 2004) 40.

30 A v Secretary of State for the Home Department [2004] UKHL 56, [2005] 2 AC 68 at [100] (Lord Hope) and [155] (Lord Scott).

31 The Supreme Court of Canada has upheld the Canadian regime on the basis that the Canadian Charter of Rights and Freedoms (s. 6) specifically provides for differential treatment of citizens and non-citizens in deportation matters: Charkaoui v Canada (Citizenship and Immigration) [2007] 1 SCR 350 (hereafter Charkaoui No. 1) at [129]. 
which a number of judges have been designated to hear cases in which confidential information is advanced. This includes, in particular, the review of executive claims in relation to security certificates issued under ss. 77(2) and 78 of the Immigration and Refugee Protection Act 2001, applications for security warrants under s. 21(1) of the Canadian Security Intelligence Service Act 1985, applications to suppress the disclosure of sensitive information under s. 38.04 of the Canada Evidence Act 1985, and decisions to list an organisation as a terrorist entity under subss. 83.05(1) and (5) of the Criminal Code of Canada. Typically, after examining confidential information at a closed hearing, the Federal Court judge decides whether the information can be disclosed to the individual by way of partial disclosure or a summary. Notably, although Canadian law after 2002 moved away from the use of a separate counsel to represent the individual's perspective in closed proceedings, ${ }^{32}$ this changed as a result of the Supreme Court of Canada's decision in Charkaoui No. $1 .^{33}$ In that decision, the Supreme Court found that the security certificates regime was inconsistent with the principles of fundamental justice that protect the right to life, liberty, and security of the person under the Canadian Charter of Rights and Freedoms, in part because the regime did not provide for the appointment of 'an independent agent at the stage of judicial review to better protect the named person's interests'. ${ }^{34}$ The Supreme Court also cited, among other possibilities, the UK system for the appointment of a special advocate, drawn from a panel of senior barristers specialising in immigration and human rights law, whose role is to represent the interests of the affected individual in closed hearings and who is given access to the confidential information put forward by the executive. ${ }^{35}$

In both countries, therefore, judges are tasked with the review of secret evidence, alongside any open evidence, before deciding whether to uphold a claim to non-disclosure on national security grounds by the executive. The individual is not denied any and all opportunity to reply to the executive's claims. Rather, the

32 The review of confidentiality claims in Canadian immigration proceedings was originally carried out by the Security Intelligence Review Committee (SIRC) as part of SIRC's investigation and review of government determinations that an individual was inadmissible to Canada based on an alleged threat to security. SIRC's review role was bypassed by legislative reforms in 1988 in the case of security certificates against foreign nationals, and in 2002 in the case of certificates against permanent residents, in favour of review by the Federal Court of Canada (now simply the Federal Court). The SIRC process, unlike the Federal Court, had provided for the appointment of a special counsel to act on behalf of the individual's interests in closed proceedings and to negotiate with CSIS about the disclosure of a summary of secret evidence, under the supervision of the presiding member of SIRC.

33 Above n. 31.

34 Ibid. at [3].

35 Special Immigration Appeals Commission Act 1997, s. 6(1); SIAC Rules, r. 35. 
individual is denied access to what may be central aspects of the state's case and is therefore unable to fashion a reply and exercise procedural rights in an informed way.

\section{The weaknesses of adjudicative review in closed proceedings}

The conflict of interest that is inherent in hidden government presents a major concern for adjudication because of the ways in which secrecy tends to undermine truth-seeking. Three weaknesses in particular confront courts when faced with secret evidence. The first weakness arises from the denial of access to the evidence by the affected individual and by the public. The second arises from the courts' dependence on executive agencies, including foreign governments, to supply and characterise the confidential information from which secret evidence is drawn. The third arises from the adjudicative dynamic that secrecy generates in the security context, which may condition a judge over time to favour secrecy over disclosure. Each of these limitations is now examined.

\section{(a) The absence of the individual and the public}

The first set of limitations in closed proceedings arises from the inability of the individual to present a reply to claims against him or her by probing or elaborating upon the record and by presenting an informed counter-argument. The court is deprived of the fruits of a counter-investigation by the affected individual in response to the executive's case. ${ }^{36}$ The court will not hear exculpatory evidence that the individual alone may be in a position to supply or uncover. ${ }^{37}$ State witnesses will not be subjected to cross-examination in contradiction of the venerated principle that evidence must be open to denunciation by the opposing party. Further, the court is denied the benefit of hearing a properly informed argument from the individual. Thus, core safeguards of the adversarial process are lost. ${ }^{38}$

In the absence of the individual party, the judge in a closed proceeding may be compelled to challenge more directly the executive's case on behalf of the individual. ${ }^{39}$ He or she may attempt to represent the individual's interest in

36 J. K. Hugessen, 'Watching the Watchers: Democratic Oversight', Paper presented to the Canadian Institute for the Administration of Justice's conference on 'Terrorism, Law and Democracy: How is Canada changing following September 11?' (Montreal, 25-26 March 2002) 384-5; Council of Europe (Commissioner for Human Rights), Report by Mr Alvaro-Gil Robles, Commissioner for Human Rights, on his Visit to the United Kingdom 4th-12th November 2004, CommDH (2005) 6 at para. 21.

37 Leigh, above n. 8 at 118 .

38 Yaroshefsky, above n. 7 at 1066 and 1071.

39 P. Duff, 'Disclosure of Evidence and Public Interest Immunity' (2007) 10 Scots Law Times 63 at 66; Leigh, above n. 8 at 137. 
reviewing the written record, questioning state witnesses, and searching for further evidence that might benefit the individual. This judicial straddling of the line, although necessary, is not a satisfactory arrangement. The judge is less able to represent the individual than would be the individual's own lawyer, first because the judge has no access to information the individual would otherwise share with counsel in privileged discussions about how to prepare for and present the case. ${ }^{40}$ The judge may not hear whether the accused has an alibi at a key moment or whether there is some innocent explanation for allegedly suspicious activity. In the words of the Supreme Court of Canada in Charkaoui No. 1, "the judge, sitting alone in closed proceedings, simply cannot fill the vacuum left by the removal of the traditional guarantees of a fair hearing'. The judge 'is not in a position to compensate for the lack of informed scrutiny, challenge and counter-evidence that a person familiar with the case could bring. ${ }^{41}$ In addition, unlike the individual's lawyer, the judge must exercise restraint when probing the executive's evidence and argument in order to protect the court's neutrality. ${ }^{42} \mathrm{~A}$ judge can question state witnesses aggressively, for example, only at the risk of undermining his or her credibility as the ultimate decision-maker. Because he or she is 'the only person in the justice system whose sole obligation and loyalty is to the defendant', ${ }^{43}$ an individual's own lawyer is uniquely positioned to advocate for the individual. ${ }^{44}$

\section{A comparison to the criminal context}

It might be argued that ex parte proceedings and secrecy are not unknown in the criminal context and, as such, that restrictions on confidentiality in non-criminal proceedings-where the consequences for the individual are less serious-should not be discounted. In particular, doctrines of privilege or public interest immunity in criminal proceedings may permit the Crown to seek judicial approval to withhold relevant information from the accused in order, for example, to enable a vulnerable witness to testify, to protect the identity of a confidential informer, or to protect national security. But however significantly these doctrines may affect the determination of guilt or innocence in a criminal proceeding, the cloak of secrecy that they extend is more limited than in other security-related proceedings. First, it does not extend to the actual evidence

40 Hugessen, above n. 36 at 384 .

41 Charkaoui No. 1, above n. 31 at [63] and [64].

42 J. Jackson and S. Doran, Judge Without Jury (Clarendon Press: Oxford, 1995) 134-5.

43 Dratel, above n. 10 at 81 (original emphasis).

44 In recognition of these limitations to adjudicative review arising from the absence of the individual, the regimes for secret evidence in both the United Kingdom and Canada provide for the appointment of a surrogate counsel, known as a special advocate, to represent the individual in closed proceedings. This procedural adaptation to the use of secret evidence is discussed briefly in the conclusion of this article. 
adduced at trial in support of the Crown's case or to the allegations directed against the individual. Secondly, it is subject to tight controls requiring the withdrawal of the charge by the Crown or dismissal of the case by the court, where the evidence goes to a central issue in the trial.

Consider the Canadian approach to informer privilege in criminal proceedings. In such proceedings, the identity of an informer may be withheld from the accused where the information supplied by the informer was given to police on the express or implied condition that the informer's identity be shielded by the executive. ${ }^{45}$ This is so despite the fact that disclosure of the contents of such evidence or aspects of its origins (such as financial or other incentives given to the informer by the executive) would better enable the individual to understand and respond to the executive's claims. ${ }^{46}$ Informers may have reason to fabricate or embellish information they provide, for example in order to avoid prosecution or deportation, ${ }^{47}$ and, without knowing the identity of an informer, an individual cannot identify reasons-of which he or she may be uniquely aware-that cast doubt on the informer. Yet confidentiality is accepted, within 1 imits ${ }^{48}$ in order to protect the state's capacity to investigate and apprehend criminal activity. Similarly, in non-criminal security proceedings, a primary rationale for secrecy is the need to protect the state's ability to establish relationships with informers who have knowledge of potential security threats by making credible commitments to protect their identity.

On the other hand, informer privilege is restricted to information that arises in the course of the investigation of an offence, and does not extend to information introduced as actual evidence at trial. The purpose of information derived from a confidential informer is typically to allow the police to show reasonable and probable grounds to obtain a search warrant. The confidentiality of tips thus serves as a means to obtain other, disclosable evidence for use at trial. While the identity of the tipster whose information provided the basis for a warrant may be

45 R v Leipert [1997] 1 SCR 281 at [9]-[12].

46 To illustrate, the content of a tip by an informer that a person attended a meeting of an organisation on a specific date would typically require protection in order not to reveal the source, whereas the content of a tip that the person is believed to be a member of the organisation might be disclosed without this danger.

47 S. Greer, Supergrasses (Clarendon Press: Oxford, 1995) 275-6; D. V. Ward, 'Confidential Informants in National Security Investigations' (2006) 47 Boston College L Rev 627 at 636-7 and 652-6; R. M. Bloom, Ratting: The Use and Abuse of Infomants in the American Justice System (Praeger: Westport, CT, 2002).

48 See R v Davis [2008] UKHL 36, [2008] 2 Cr App R 33 where the House of Lords unanimously quashed the conviction and ordered a new trial on the basis that allowances for witness anonymity had rendered the first trial unfair. 
kept confidential, evidence derived from the search will be disclosed to the accused. Moreover, even at the investigative stage, the courts emphasise the need for careful scrutiny of information supplied by confidential informers where the information supports a search warrant application. ${ }^{49}$ The Supreme Court of Canada has indicated that a 'bald conclusory' tip by an informer is insufficient to demonstrate reasonable and probable grounds for a warrant and has emphasised that information from a confidential informer must be compelling, credible, and corroborated by a police investigation before the courts will authorise a search. Also, where the credibility of the informer cannot be assessed because the informer is anonymous or untried, this must be compensated by the quality of the information and corroborative evidence. ${ }^{50}$ Confidential information relating to informer privilege is thus approached with caution at the investigative stage and subject to disclosure if relied on at trial.

In contrast, in other security-related proceedings-including UK control order and Canadian security certificate proceedings-there is broad scope for the use of testimony (including hearsay) derived from confidential informers as part of the evidentiary foundation for the state's case. In the security field, human intelligence sources commonly do not take the stand even in a closed proceeding and so they are never questioned directly and under oath about their version of events. Instead, a security official testifies as to the source's story or, in some cases, presents information drawn from a report from the field officer who had contact with the informer, but who also may never testify under oath. In such circumstances, the risk of error or abuse is magnified greatly from that in a criminal trial where the evidence adduced will be disclosed, although it was derived from a search that was triggered originally by a confidential tip. Both criminal and non-criminal proceedings share a common security-based rationale for attempting to balance the competing interests in confidentiality and disclosure, but they achieve that compromise in very different ways. ${ }^{51}$

A second example can be found in the approach to claims of public interest immunity in criminal proceedings in England and Wales as examined in decisions of the European Court of Human Rights (ECtHR). ${ }^{52}$ The immunity is typically

$49 \mathrm{R}$ v Debot [1989] 2 SCR 1140 at 1168-9. See also Nova Scotia (AG) v Macintyre [1982] 1 SCR 175. On informer's privilege and search warrant applications, see S. Penney, E. Rondinelli and J. Stribopoulos, Criminal Procedure in Canada (LexisNexis: forthcoming, 2009) ch. 3. On confidentiality and wiretapping warrants, see Leigh, above n. 8 at $126-7$.

50 R v Debot [1989] 2 SCR 1140 at 1170-1, above n. 49.

51 On US approaches to confidential informers in criminal and national security proceedings, see Ward, above n. 47.

52 Rowe and Davis v United Kingdom (2000) 30 EHRR 1; Jasper v United Kingdom (2000) 30 EHRR 97; Fitt v United Kingdom (2000) 30 EHRR 223. 
asserted as a basis for restricting the duty of the Crown to disclose relevant information to the accused. ${ }^{53}$ But again this involves a decision by the Crown to withhold information that it would otherwise disclose; it does not extend to the actual use of secret evidence at trial. Moreover, the ECtHR and English domestic courts have placed a series of restrictions on the assertion of the privilege in order to ensure the right to a fair and public hearing in criminal cases. In particular, the ECtHR concluded in Rowe and Davis that the restriction on the rights of the defence must be 'strictly necessary' and that any difficulties caused to the defence must be sufficiently counterbalanced by the adoption of adequate procedural safeguards. ${ }^{54}$ Also, the ECtHR found non-compliant a procedure in which the prosecution itself attempts to assess the importance of concealed information to the defence and weigh this against the public interest in keeping the information secret'. Importantly, it was up to the judge at trial to determine issues of relevance and disclosure because it was the trial judge 'who saw the witnesses give their testimony and was fully versed in all the evidence and issues in the case' and because he or she 'would have been in a position to monitor the need for disclosure throughout the trial, assessing the importance of the undisclosed evidence at a stage when new issues were emerging, ${ }^{55}$ Again, these limitations on secret evidence in criminal proceedings are not present in non-criminal security-related proceedings where the state may withhold its evidence and detailed allegations from the individual, where the duty of disclosure is less categorical, and where (as under the Canada Evidence Act) issues of relevance and disclosure are determined by a judge other than the judge in the underlying substantive proceeding.

\section{The absence of the public}

Alongside limitations arising from the absence of the individual is the obvious corollary that the public also has no access to closed proceedings. The absence of the public is a significant limitation. ${ }^{56}$ It raises accountability concerns in general and more specifically in security-related proceedings where secrecy is necessarily pervasive and typically permanent. First, keeping evidence secret means that witnesses will not testify, and government counsel will not present argument, under public scrutiny and third parties who may have relevant information-but who will be able to come forward only if made aware of the evidence-cannot do so. ${ }^{57}$ This poses a risk beyond that present in open proceedings that the adjudicative

53 R. Munday, Evidence, 3 rd edn (Oxford University Press: Oxford, 2005) 151-2; R. Scott, "The Acceptable and Unacceptable Uses of Public Interest Immunity" [1996] Public Law 427 at 427-8.

54 Rowe and Davis v Untted Kingdom (2000) 30 EHRR 1 at [61], above n. 52.

55 Ibid. at [65].

56 Marcus, above n. 16 at $207-8$.

57 Dagenais v Canadian Broadcasting Corp. [1994] 3 SCR 835 at 882-3. 
decision will be founded on incomplete or inaccurate information. Revealing the evidence to a representative of the individual (or to the individual himself or herself) on condition of confidentiality does not address this concern because it precludes third parties from being informed in follow-up investigations.

Secondly, the absence of the public hampers the judge's ability to look behind the state's case against the individual and its reasons for secrecy. The need for systematic secrecy means that courts are less able to hear from independent experts, for the simple reason that few outside government are able to develop sophisticated and well-informed expertise in the field. There are experts, often retired security officials, who can offer expertise that is informed by extensive experience in the work and techniques of security intelligence. But this expertise remains concentrated in a small group of persons who have past connections to government. Even where an expert independent of the security agencies is called to testify on the evidence and the rationales for secrecy in a particular case, the expert will be shut out from the closed loop of up-to-date information, examined with reference to other live intelligence files, that is available to the insider. The executive becomes by default the judge's guide to the murky world of security intelligence, ${ }^{58}$ tasked with outlining the state's current priorities in relation to the case against the individual, its information-sharing practices, the motivations of foreign governments, the strengths and weaknesses of its investigative techniques, and so on. This of course does not mean that sensitive information should be released in order to support the development of a wider base of expertise on security intelligence. But it does indicate that secrecy in the security context has wider implications for adjudicative decision-making over and above its impact on the instant case.

\section{(b) Dependence on the executive}

A second set of limitations arises from the courts' dependence on the executive, above all its security arm, to be fair and forthcoming in supplying confidential information, in depicting how the information was acquired and selected for presentation to the court, and in producing all information in the state's custody that may be beneficial to the individual. In a closed proceeding, the judge is not in a position to review the underlying record of information held by the executive. As a result, greater opportunities arise for error or abuse than in cases where a more extensive duty of disclosure applies or where alternative, independent means of investigation are available..$^{99}$

58 G. E. Rosen, 'Remarks of Judge Gerald E. Rosen-the War on Terrorism in the Courts' (2004) 21 TM Cooley L Rev 159 at 164.

59 E. Margulies, 'Above Contempt?: Regulating Government Overteaching in Terrorism Cases' (2005) Southwestern UL Rev 449 at 475. 
Security agencies assess the reliability of information in order to make decisions about threats to security and about possible responses. Their mandate is not to assess evidence against legal standards. In Manget's words: 'Intelligence looks forward and provides an estimate of what is happening and what will happen. Everyone is guilty until proven innocent, and innocence does not last'. ${ }^{60}$ When confronted with secret evidence, therefore, a court depends on the executive not only to be fair and forthcoming in its presentation of the state's case, but also to adapt its ingrained methods of analysis and assessment to an adjudicative environment. This opens the door not simply to intentional abuse but also to unintended error or misrepresentation in the presentation of security intelligence as evidence.

These concerns are accentuated by documented instances in which the courts' trust of the executive on matters of secrecy has been betrayed. ${ }^{61}$ A number of instances of the manipulation of secrecy by government officials in order to avoid embarrassment to themselves or the government came to light as a result of the Arar Inquiry in Canada. ${ }^{62}$ For example, it was revealed that the Royal Canadian Mounted Police (RCMP) had previously misled a Canadian court on the likelihood that secret evidence obtained from Syrian Military Intelligence, and used to support an application by police for a warrant, was the product of torture. ${ }^{63}$ This fact was disclosed publicly only after the Inquiry released its reports and sought a court order to authorise disclosure over the objections of the government. The

60 F. F. Manget, 'Intelligence and the Criminal Law System' (2006) 17 Stan L \& Policy Rev 415 at 416 . See also C. Walker, 'Intelligence and Anti-terrorism Legislation in the United Kingdom' (2005) 44 Crime, Law and Social Change 387 at 388.

61 Bhupinder S. Liddar v Deputy Head of the Department of Foreign Affairs and International Trade and Canadian Security Intelligence Service, File No. 1170/LIDD/04 (7 June 2005) at para. 72; Atwal v Canada (Solicitor General) [1988] 1 FC 107 (TD). Dratel, above n. 10 at 100; M. Scaperlanda, 'Are We That Far Gone?: Due Process and Secret Deportation Proceedings' (1996) Stan L \& Policy Rev 23 at 28; D. Cole, 'Enemy Aliens' (2002) 54 Stan L Rev 953 at 1001-2; S. M. Akram and K. R. Johnson, 'Race, Civil Rights, and Immigration Law after September 11, 2001: The Targeting of Arabs and Muslims' (2002) 58 NYU Ann Surv Am L 295 at 324-5; N. T. Saito, 'The Enduring Effect of the Chinese Exclusion Cases: The "Plenary Power" Justification for On-Going Abuses of Human Rights' (2003) 10 Asian LJ 13 at 19-20; Note, 'Secret Evidence in the War on Terror' (2005) 118 Harv L Rev 1962 at 1979-80; J. Lu, 'How Terror Changed Justice: A Call to Reform Safeguards that Protect Against Prosecutorial Misconduct' (2006) 14 J L \& Policy 37'7 at 379-80.

62 Commission of Inquiry into the Actions of Canadian Officials Relating to Maher Arar (Canada), Report of the Events Relating to Maher Arar-Analysis and Recommendations (Ottawa, 2006) (hereafter Arar Report-Analysis and Recommenaations) 255-63. The Inquiry's mandate was to examine the role played by Canadian officials in the detention and removal of the Canadian citizen Maher Arar by US authorities, and his subsequent imprisonment and torture in Syria.

63 Commission of Inquiry into the Actions of Canadian Officials Relating to Maher Arar (Canada), Report of the Events Relating to Maher Arar-Addendum-Disclosure of information authorized by the Federal Court of Canada in accordance with Sections 38.04 and 38.06 of the Canada Evidence Act (Ottawa, 2007) $127-8$. 
government resisted disclosure, purportedly on security grounds, for more than two years after the establishment of the Inquiry. The lesson is that, where the executive misleads a court about secret evidence, the truth is unlikely to emerge without sustained pressure by an independent entity with detailed knowledge of the underlying record of the case. Without thorough, independent review of the executive's claims it will be impossible for a judge, let alone those denied access to closed proceedings, to know whether secrecy powers have been misused. ${ }^{64}$

\section{Information supplied by a foreign source}

Judicial dependence on the executive is especially problematic where secret evidence originates in a foreign government. This is not uncommon. A key rationale for national security confidentiality is the need for the state to honour its commitments (or 'caveats') to foreign entities. This rationale is especially compelling in the security context because a state is often able to acquire information from other states only by agreeing not to pass it on to third parties. A state must therefore be able to make credible promises of confidentiality in order to protect its ability to engage in information-sharing ${ }^{65}$ Yet, for a court, foreignsourced information presents special quandaries because it calls for scrutiny of at least three actors: the original source, the authorities of the providing state, and the authorities of the receiving state. Each actor may have reasons to filter or fabricate information.

The court's task thus extends to the assessment of foreign entities and sources and of the likelihood that they may have erred in presenting information, withheld relevant material, relied on inappropriate interrogation methods, or deceived the receiving state for their own purposes. In conducting this assessment, neither the court nor its security agencies may be able to know with confidence how the foreign government acquired or produced the information or whether it was filtered through third states. For example, who in the receiving state will be able to say whether a confession by a prisoner in another state has been coerced or fabricated? An obvious danger is that the foreign government has actively misled the receiving state; we are speaking of the world of espionage as well as intelligence after all. The court may not know whether and how the information wound its way through the security apparatus of other states ${ }^{66}$ and may not be privy to the

64 The US Foreign Intelligence Surveillance Court recently condemned the Federal Bureau of Investigation for giving false or misleading evidence in 75 security warrant cases under the Foreign Intelligence Surveillance Act: Re Sealed Case, 218 F Supp 2d, 620, rev'd 310 F 3d, at 735.

65 For example, Ruby v Canada (Solicitor General) [2002] 4 SCR 3 at [44].

66 M. M. O'Neil, 'Crawford v Washington: Implications for the War on Terrorism' (2005) 54 Catholic U L Rev 1077 at 1091. 
foreign policy motivations and machinations of the foreign government. ${ }^{67}$ The court cannot call foreign officials to testify and is unlikely to hear testimony from, or even to know the identity of, informers abroad. The court is thus seriously hampered in its ability to probe the executive's case.

The court in the receiving state relies in closed hearings on its own government and, especially, on the agencies that deal regularly in the information exchange in security matters. But those agencies have wider relationships with other governments that they must cultivate as part of their mandate to collect useful information. An agency's responsibility to serve the court may be important, but it remains one consideration alongside others in the agency's pursuit of its mission to identify and protect against threats. In the course of this mission, individuals may become useful bargaining chips in international dealings with other entities. ${ }^{68}$ Alternatively, a security agency may be reluctant to question before a court the reliability or motivations of a foreign government with which it has an ongoing relationship, especially after the agency has chosen to put before the court information from that government. In these respects, a judge may not be fully informed of the exigencies of its security agencies' dealings with a foreign government that has supplied secret evidence.

Another danger is that officials from different states could seek to manipulate information exchange in order to construct rationales for secrecy in each other's jurisdictions. Because it is the executive that initiates proceedings against the individual, while also deciding how its information-sharing arrangements are constructed and negotiated, the court should not extend blanket protections from disclosure to foreign-sourced information nor should it lower evidentiary standards that otherwise apply to the types of evidence proffered. Doing so opens the door to the artificial use of foreign caveats as a vehicle to inoculate information against disclosure and against the rigours of the ordinary legal process. Likewise, where the executive proposes to use foreign-sourced information as

67 The foreign agency may wish to discredit political opponents abroad by spreading false information about them: W. Schabas, 'Fair Trials and National Security Evidence' (2006) 4 Int'1 $^{3}$ Commentary on Evidence, Article 9 at 4; J. Ramji-Nogales, 'A Global Approach to Secret Evidence: How Human Rights Law Can Reform Our Immigration System' (2008) Legal Studies Research Paper Series, Paper No. 2008-38<http//papers.ssm.com/sol3/papers.cfm?abstract_id=1080317>, accessed 16 October 2008, at 18, citing Re Ahmed, No. A90-674-238 (NY, Immig Ct, 30 July 1999) at 14-15.

68 A. B. Spiegel, 'Human Rights Versus National Security' (1981) 4 Houston J Int'l L 148 at 153, citing Stein v Depariment of Justice (No. 77 C 954), details of which were leaked to the Chicago Sun Times (9 April 1980) at 3 and (15 October 1979) at 1 (involving a Chicago attomey who handled numerous political asylum cases on behalf of Polish immigrants, and who discovered through a Freedom of Information request that the FBI had compiled a dossier on him and was turning over personal and confidential information they had gathered to the Polish secret police). 
secret evidence, the court should hold the executive to a reasonable duty to negotiate with the providing state in order to maximise disclosure. ${ }^{69}$ The executive's decision to agree to a caveat when receiving foreign information could also be taken as an election to limit the extent to which such information can be introduced in an adjudicative process against an individual. The integrity of adjudication requires that information-sharing be adapted to the demands of accuracy and fairness, not the other way around.

\section{The decision in Charkaoui No. 2}

The Supreme Court of Canada acknowledged limitations arising from judicial dependence on the executive and took steps to address them in Charkaoui No. $2{ }^{70}$ The case involved the use of secret evidence that originated in operational activities of the Canadian Security Intelligence Service (CSIS). Mr Charkaoui, a permanent resident of Canada, had been detained for 21 months pursuant to a security certificate. Prior to a fourth judicial review of his detention, the government revealed that a document that should have been disclosed to the court when the security certificate was issued had not been disclosed due to an oversight. The document was a CSIS report summarising two CSIS interviews with Mr Charkaoui that took place prior to his detention. In reply to Mr Charkaoui's request for disclosure of the notes and recordings of the interviews, the government stated that there were no recordings on file and that notes of CSIS interviews are, based on CSIS policy, systematically destroyed after the CSIS officer completes his or her report. Thus, the judge reviewing Mr Charkaoui's detention would have to rely on interview summaries prepared by executive officials.

In these circumstances, the Supreme Court found that CSIS breached its duties under the Canadian Security Intelligence Service Act and under s. 7 of the Canadian Charter of Rights and Freedoms to retain all of the information in its possession relating to security certificate investigations and to disclose that information to relevant ministers and the reviewing judge. LeBel and Fish JJ stated for a unanimous court that submission of the operational notes of CSIS officers to the court 'may be necessary to ensure that a complete and objective version of the facts is available to those responsible for issuing and reviewing the certificate'. ${ }^{71}$ They concluded also that '[i]f the original evidence was destroyed, the designated judge has access only to summaries prepared by the state, which means that it will be difficult, if not impossible, to verify the allegations' against the individual. It followed that 'the destruction by CSIS officers of their operational notes

69 Abdulah Khadrv AttomeyGeneral of Canada, 2008 FC 549 (29 April 2008) at [93]-[95].

70 Charkaoui v Canada (Minister of Citizenship and Immigration and Solicitor General of Canada) 2008 SCC 38 (hereafter Charkaoui No. 2).

71 Charkaoui No. 2, above n. 70 at [42]. 
compromises the very function of judicial review, ${ }^{72}$ These concerns reflect the wider limitations arising from judicial dependence on the executive in closed proceedings, which are further explored in the next section of this article.

\section{(c) The dynamic of closed proceedings}

Closed proceedings in the security context have a dynamic that is unlike other confidential adjudication owing to a combination of factors that may encourage the courts, sometimes in subtle ways, to favour unduly the executive's position over that of the individual. This tendency is in part the outcome of the two factors previously discussed-the absence of the individual and the public, and the courts' dependence on the executive-both of which contribute to an adjudicative environment in which the security interest obtains a privileged status as a result of its more direct and responsive representation before the court. Besides this, a judge may lean toward the executive's position for more diffuse reasons arising from the dynamic of closed proceedings and from the type of issues that arise in confidentiality review. ${ }^{73}$

\section{The atmosphere of closed hearings}

In the first place, closed hearings have a unique tone and atmosphere that reflects the priorities and culture of the security realm. This realm is populated by officials whose raison d'etre is to identify and counter security threats and whose training and professional experience understandably press them to emphasise secrecy over disclosure, and expediency over concerns to protect the administration of justice. Other than the judge and a handful of court staff, closed hearings will be attended by government counsel, government witnesses, and government observers who are all drawn from or connected to the security realm. Other than the judge, the only experts (legal and non-legal) in the room in which the hearing takes place will be those of the state, and they will have exclusive access to and control over the background information and underlying record for the case. Thus, they will have incomparably specialised expertise in the most arcane of fields. ${ }^{74}$ In these respects, the executive's presence looms large, both physically and psychologically, as a constant reminder of the security interest.

This environment need not influence the judge in an overt or conscious way, but it may contribute over time to a dynamic in which security and secrecy crowd out other priorities. ${ }^{75}$ One need not suspect that security officials have actively misled

72 Charkaoui No. 2, above n. 70 at [61]-[62].

73 Margulies, above n. 59 at 459.

74 Margulies, above n. 59 at 465.

75 Leigh, above n. 8 at 159. 
a judge in a particular case in order to accept that judicial review of the executive in these matters is shaped by how security officials present their activities and vet the information they collect before putting it before the court, and by their own vulnerability to errors that an open process would otherwise deter or uncover ${ }^{76}$ Even where a judge is not swayed by 'nightmarish tales of national security problems," he or she must confront serious obstacles to peeling away any layers of obfuscation or to uncovering any subtle bending of the truth on the part of security officials.

\section{Lack of judicial expertise}

A key reason for the courts' hesitancy to question the executive, especially in its characterisation of the implications of disclosure of confidential information, is the reviewing court's acknowledged lack of pertinent expertise. It is a very complex task to evaluate confidential information or intelligence, predict how its release may harm the security interest, weigh this risk against the need for openness and fairness, devise ways to maximise disclosure without allowing the intricacies of document review to overwhelm the adjudicative process, and regulate compliance by the executive with court orders to release information. Each of these elements of the process may in turn engage wide-ranging issues such as the novelty of investigative techniques, the effectiveness of data-mining software, the conditions of a witness's imprisonment in a foreign country, the motivations of a foreign agency to share information, the immutability of governmental caveats, and so on. ${ }^{78}$

In examining these issues, a court must be sensitive to challenges faced by the security agencies. ${ }^{79}$ It is a difficult undertaking to identify and evaluate clandestine threats and viable responses under conditions of systematic secrecy. This task calls for laborious collection, classification, analysis, distribution, and prioritisation of vast data sets collected from disparate sources of varying reliability. It involves targets of investigation whose networks are evolving, who conceal their aims and connections, and who may be prepared to exploit the freedoms of a democratic society. It would be difficult if not simply unrealistic for a judge to become well versed in the full panoply of threats associated with diverse

76 Margulies, above n. 59 at 476 ; Rosen, above n. 58 at 168; Note, 'The National Security Interest and Civil Liberties' (1972) 85 Harv L Rev 1130 at 1134.

77 R. P. Salgado, 'Government Secrets, Fair 'Trials, and the Classified Information Procedures Act' (1988) 98 Yale L) 427 at 429 and 438.

78 Note, 'Executive Privilege and the Freedom of Information Act: The Constitutional Foundation of the Amended National Security Exemption' (1976) Washington Univ LQ 609 at 660-2.

79 B. J. Narain, 'Confidentiality, National Security, and the Right to Know-The Spycatcher Decision' (1988) 39 N Ireland Leg Quarterly 73 at 73-4. 
organisations, governments, and regions of the world. Indeed, it may in some cases appear futile for the court to attempt to determine all of the implications of a decision to release confidential information to the public or to the individual, in the course of the court's balancing of competing rationales for disclosure and secrecy. ${ }^{80}$ The recognition by judges of their relative lack of expertise in these respects explains much of the courts' tendency to accept executive overtures for deference in the security field. ${ }^{81}$

By the same token, courts 'ought not to panic at the mere mention of national security and abdicate their inherent power in common law', as Narain puts it. ${ }^{82}$ The courts have their own realm of expertise and a profound responsibility to ensure that the protection of security does not sacrifice core principles of the administration of justice. ${ }^{83}$ Security agencies likewise do not have expertise in managing the risks of secrecy in legal decision-making, and their views on whether and how closed proceedings should be permitted may be influenced by their mandate to counter security threats. There is also a record of over-claiming confidentiality (as well as selective leaking) in security matters, including in adjudicative proceedings. ${ }^{84}$ It is therefore important for the courts to adopt openness as an initial presumption and require the executive to establish compelling reasons for non-disclosure in respect of particular items of evidence. ${ }^{85}$ It is one thing for a court to defer generally to the executive in security matters; it is another for courts to accept the state's confidentiality claims over core elements of its case against an individual without reviewing in detail the information and proposed rationale for secrecy, without carefully considering options to maximise disclosure, and without requiring the executive to choose, where necessary, either to disclose the evidence or to accept dismissal of its relevant claims. ${ }^{86} \mathrm{~A}$ court neglects its duty to insulate the adjudicative process from the conflict of interest in hidden government when the court is overly compliant in accepting what was called, by US Senator Muskie, 'the outworn myth that only those in possession of

80 R. S. Holzer, 'National Security Versus Defense Counsel's "Need to Know": An Objective Standard for Resolving the Tension' (2005) Fordham L Rev 1941 at 1949.

81 Secretary of State for the Home Department v Rehman [2003] 1 AC 153. R. P. Deyling, "Judicial Deference and De Novo Review in Litigation Over National Security Information Under the Freedom of Information Act' (1992) 37 Vill L Rev 67 at 69; C. D. Ablard, 'Judicial Review of National Security Decisions: United States and United Kingdom' (1986) 27 Wm \& Mary L Rev 753.

82 Narain, above n. 79 at 84.

83 S. Brown, 'Public Interest Immunity' [1994] Public Law 579 at 589.

84 Arar Report-Analysis and Recommendations, above n. 62 at 260 and 301-4. See above n. 61.

85 Abdullah Khadr v Attomey General of Canada 2008 FC 549 at [98]. For a discussion of class claims in public interest immunity cases, see P. Roberts and A. Zuckerman, Criminal Evidence (Oxford University Press: Oxford, 2004) 238-40.

86 Manget, above n. 60 at 423; Salgado, above n. 77 at 436 and 442; Yaroshefsky, above n. 7 at 1088; Leigh, above n. 8 at $154-5$. 
military and diplomatic confidences can have the expertise to decide with whom and when to share their knowledge'. ${ }^{87}$

\section{The mosaic theory}

In terms of expertise, the terrain of inquiry in national security matters has an especially opaque and high-stakes quality. Threats are often not clear even to security officials and yet can easily be seen by anyone to carry potentially catastrophic consequences. This high-stakes uncertainty provides the backdrop for the 'mosaic theory' of non-disclosure. The theory posits that, even where apparently innocuous information is disclosed, an informed observer may be able to piece together information or combine it with other information known to the observer in order to construct a more comprehensive picture of state secrets. ${ }^{88}$ The theory represents an ultra-precautionary approach to the disclosure of security intelligence. ${ }^{89}$ It can be used to support a claim that disclosure of virtually any evidence classified as secret by the executive will harm national security. In Pozen's words, 'highly speculative mosaic claims are unfalsifiable; in practice, they have proven unimpeachable'. ${ }^{90}$ The difficulty then is that the theory's breadth may cause courts to defer to the state's confidentiality claims without engaging in rigorous analysis of whether and how abstract and generalised rationales for confidentiality actually apply to specific pieces of information. In many cases, courts have relied on the mosaic theory to support a highly deferential approach to the state's case for secrecy..$^{91}$

A sceptical approach to the mosaic theory was adopted by Mosley J of Canada's Federal Court in Khadr, which involved an application for the disclosure of information subject to the national security confidentiality provisions of s. 38 of the Canada Evidence Act. In Khadr, the mosaic theory was advanced by the Attorney-General to support a confidentiality claim over various pieces of information relevant to $\mathrm{Mr}$ Khadr's defence in extradition proceedings, including the fact that Canadian officials had been informed three years earlier that US authorities paid a bounty to Pakistan for Mr Khadr's capture prior to his detention and alleged abuse at the hands of US agents and Pakistani officials. Following a detailed review, MosleyJ ordered disclosure of the information that he found to be

87 Senator Muskie, Remarks, 120 Cong Rec (daily edn May 30, 1974) §9319.

88 Abdullah Khadrv Attomey-General of Canada 2008 FC 549 at [73].

89 D. E. Pozen, 'The Mosaic Theory, National Security, and the Freedom of Information Act' (2005) Yale LI 629 at $663-6$.

90 Pozen, above n. 89 at 679.

91 For example, Henrie v Canada (Security Intelligence Review Committee) (1989) 53 DLR (4th) 568 at $578-9$. C. E. Wells, 'ClA v. Sims: Mosaic Theory and Government Attitude' (2006) 58 Admin L Rev 845 at $863-6$. 
relevant to the extradition proceeding, including the payment of the bounty. The court found that disclosure of this fact, in particular, would not injure national security because three years had passed since the information was received by Canadian officials, the general practice of paying bounties was in the public domain, no human source appeared to be at risk, and the circumstances in Pakistan had changed since these events took place. ${ }^{92}$

Most importantly for present purposes, Mosley J concluded that the mosaic theory, without supporting evidence, was insufficient to establish that disclosure would injure national security. He said that '[a]s a matter of logic, the concept has some appeal but there is no apparent limit to how far it may be taken. Carried to an extreme, the theory would justify the withholding of all information no matter how innocuous'. ${ }^{93}$ Mosley $J$ also cautioned that ' $[w]$ itnesses from the intelligence community may take the mosaic effect theory as an article of faith, relying upon it as a complete answer to the release of information they consider sensitive or potentially harmful. ${ }^{94}$ This important ruling indicates not only the limits of the mosaic theory as an all-encompassing rationale for confidentiality, but also the capacity of judges to reject over-broad claims about the need for secrecy. On the other hand, aspects of the decision in Khadr are somewhat exceptional, for reasons discussed below.

\section{The contest of attrition in security confidentiality review}

A judge is usually in a position to release confidential information only after a time-consuming and often testing interaction with the executive in secret. ${ }^{95}$ The process of confidential document review is complex and laborious. Myriad issues will arise in the assessment of the relevance of information to the underlying proceeding, the potential harm arising from disclosure, and the trade-offs between secrecy and disclosure. These issues will be multiplied by the number of distinct pieces of information that are under consideration for disclosure. The relationship between reasons for and against disclosure may be fluid, requiring ongoing review as risks evolve or other information finds its way into the public domain. The process will be cumbersome, all the more so where the executive adopts the strategy of embroiling the judge or special advocate in a contest of

92 Abdullah Khadr v Attorney-General of Canada 2008 FC 549 at [111]. Other information relevant to Mr Khadr's defence in the extradition proceedings was also ordered to be disclosed to him, although not to the public, on the basis that the public interest in this restricted disclosure outweighed the public interest in keeping it secret.

93 Abdullah Khadr v Attomey-General of Canada 2008 FC 549 at [77].

94 Ibid.

95 C. Stracher, 'Eyes Tied Shut: Litigating for Access under CIPA in the Government's "War on Terror"' (2003) 48 NY L Sch L Rev 173 at 179-80. 
attrition. ${ }^{96}$ In such circumstances, there is a danger that the judge, facing a long and arduous struggle with the executive, will be discouraged from undertaking the meticulous scrutiny that is required to maximise disclosure. ${ }^{97}$ He or she may be induced to opt for secrecy as the most practical way to contend with a seemingly endless stream of objections by the executive.

The Khadr decision is encouraging in this respect, inasmuch as Mosley J ordered extensive disclosure of information to support Mr Khadr's defence in extradition proceedings. That said, the amount of information at stake was not overwhelming; it consisted of 266 documents comprising approximately 1,300 pages in total..$^{98}$ Mosley J expressed concern about 'the length of time that it took to complete the review of the material for disclosure purposes' but accepted that this was 'a function of the sensitivity of the information and insufficient resources'. He also noted that Crown counsel in the extradition proceeding 'voluntarily undertook to make disclosure beyond the scope of the requesting state's Record of the Case when they recognized that there was an "air of reality" to the applicant's claims. ${ }^{99}$ Lastly, both counsel to Mr Khadr and the special advocate appointed by Mosley $\mathrm{J}$ in the case were able to make relatively well-informed submissions on disclosure because much of the information had been previously (and, according to the Attorney-General, inadvertently) disclosed to $\mathrm{Mr}$ Khadr-and in one instance to a newspaper-in the course of the extradition proceeding. ${ }^{100}$ These pre-existing revelations enhanced the adversarial character of the closed proceedings in Khadr and may have helped to counter other pressures tending to favour secrecy.

\section{Conclusion}

Three weaknesses of adjudication in the face of secret evidence have been elaborated: the inability of the individual to make an informed reply to the state's case, the unique dependence of the court (and the individual) on the executive, and the dynamic of closed hearings that tends to favour the security interest. These limitations may be intractable, especially when secret evidence originates in foreign-sourced information. Executive reliance on such information enmeshes the court in a web of dependencies on persons and organisations operating beyond its authority and, in many cases, beyond proper scrutiny by its own security agencies. In the face of these weaknesses, various procedural adaptations

96 Deyling, above n. 81 at 94 and 108-9; P. Shenon, Judge Critical of Secrecy in Terror Case Prosecution' New York Times (4 April 2003).

97 Deyling, above n. 81 at 105; Groner, 'Iran-Contra Trial Snagged on Classified Documents' Legal Times (18 April 1988) 3.

98 Abdullah Khadr v Attomey-General of Canada 2008 FC 549 at [15], above n. 92.

99 bid. at [121].

100 Tbid. at [18]-[19]. 
may assist in ameliorating the limitations of secret evidence so long as they are designed and evaluated in light of the full range of relevant adjudicative weaknesses, and take appropriate account of the variable characteristics of specific procedural contexts.

To address the absence of the individual from closed proceedings, governments in the UK and Canada have allowed for the appointment of special advocates who are given access to all of the information put forward by the state, and to the closed hearings, and who are mandated to represent the individual's interests. ${ }^{101}$ This allows for a line to be drawn between the judge's role and the individual's interests, and operates as a check against closed proceedings drifting towards undue emphasis on secrecy. ${ }^{102}$ However, special advocates cannot resolve other weaknesses arising from secret evidence because they, like judges, are unlikely to have the institutionalised expertise necessary to counter the executive's mastery of security intelligence, and are similarly vulnerable to obstruction and exhaustion in the contest of attrition over confidentiality claims. ${ }^{103}$ Further, special advocates have no 'roving commission' to scrutinise the underlying files, compare cases in order to formulate a wider perspective, or investigate the reliability of foreign-sourced information, ${ }^{104}$ and so they, again like judges,

101 E. Metcalfe, "Representative but not responsible": The use of special advocates in English law' (2004) 1(2) JUSTICE Journal 11; Constitutional Affairs Committee, above n. 9 at 56-7; Bonner, above n. 27 at 276-7; C. Forcese and L. Waldman, Seeking Justice in an Unfair Process, Study commissioned by the Canadian Centre for Intelligence and Security Studies, with the support of the Courts Administration Service (2007) <http//aix1.uottawa.ca/ cforcese/other/sastudy.pdf accessed 16 October 2008.

$102 \mathrm{M} v$ Secretary of State for the Home Department, Special Immigration Appeals Commission File No SC/17/2002, Open Judgment (8 March 2004) at para. 10.

103 Constitutional Affairs Committee, above n. 9 at 56-7; N. Blake, Submissions before the International Commission of Jurists Panel, UK Hearings, 25 April 2006, 1 <http:/ejp.icj.org/IMG/ Blake_transcript.pdf $>6-8$, accessed 16 October 2008.

$104 \operatorname{Re} M B$ [2006] EWHC 1000 (Admin) at [98], where Sullivan J expressed concerns about the reliance on special advocates in closed proceedings where the special advocate does not examine what was actually known to the Secretary of State's informant, the Security Service, or whether any of the closed material on which the Secretary of State based his suspicion was in fact true'. Ultimately, in Re MB [2007] UKHL 46, a majority of the House of Lords concluded that the use of closed proceedings in which special advocates were employed could in many cases be made consistent with the right to a fair hearing in a civil context under Article 6 of the European Convention on Human Rights. However, the majority also expressed concern about the implications for procedural faimess, with Lord Bingham in particular speaking at [35] of the 'grave disadvantage' for the individual and of the role of the court in specific cases 'to decide, looking at the process as a whole, whether a procedure has been used which involved significant injustice to the controlled person'. See also at [66] (Baroness Hale) and [90] (Lord Brown). On the appointment of special advocates in parole board hearings, see $R$ (on the application of Roberts) $v$ Parole Board [2005] UKHL 45, [2005] 2 AC 738. 
remain dependent on the executive in its production and portrayal of confidential information. ${ }^{105}$

In its decision in Charkaoui No. 1, the Supreme Court of Canada discussed, alongside the use of special advocates, the adjudicative models used by the Security Intelligence Review Committee (SIRC) and by the Arar Inquiry to look behind executive claims and scrutinise the underlying record. ${ }^{106}$ Notably, both of these alternative models allowed not only for surrogate representation of the individual in closed proceedings but also for independent review of the executive's decisions regarding the selection and depiction of secret evidence. ${ }^{107}$ The models also have limitations, but they were in this respect better equipped than the special advocates model to counter weaknesses arising from dependence on the executive. In security proceedings, there is a uniquely pressing need for independent investigation of the underlying record because the material that makes up the secret evidence will rarely be made public to contemporaries or otherwise scrutinised beyond the closed proceeding.

In conclusion, it should be stressed that no procedural adaptation can entirely remove the inherent weaknesses arising from secrecy. Allowing secret evidence poses an inescapable risk that the court may be denied vital information that can be communicated only if the affected individual, or the public, is informed of the evidence. Likewise, the only way to subject those operating in closed proceedings to the disciplines of publicity is to open the proceedings. For these reasons, the courts must always ask whether, in spite of the procedural adaptations that may be available to accommodate secrecy, it is nonetheless irreparably unsafe or unfair to allow it.

105 Bonner, above n. 27 at 285-6; Forcese and Waldman, above n. 101 at $40-3$.

106 Above n. 31 at [70] and [87].

107 See Arar Report-Analysis and Recommendations, above n. 62 at 290-8; Leigh, above n. 8 at 140-1 and 162-3. 